\title{
PENGARUH PEMBERIAN PUPUK PADA POSISI VERTIKAL BATANG TERHADAP SIFAT FISIK DAN MEKANIK BAMBU PETUNG (Dendrocalamus asper (Schult. F.) Backer ex Heyne)
}

\section{(The Effect of Fertilization on the Vertical Position in the Stem to Physical and Mechanical Properties of Petung Bamboo (Dendrocalamus asper (Schult. F.) Backer ex Heyne)}

\author{
Oleh / By : \\ Abdurachman $^{1)} \&$ Saefudin $^{2)}$ \\ ${ }^{1)}$ Pusat Litbang Hasil Hutan, Jl. Gunung Batu No. 5 Bogor, Tlp/Fax: 8633413-8633378 \\ ${ }^{2)}$ Pusat Penelitian Biologi-LIPI Bogor, Jl. Jakarta Bogor, KM 46 Cibinong Sciense Center (CSC)
}

Diterima 24 Februari 2009, disetujui 22 Juli 2009

\begin{abstract}
This research aimed to investigate the effect of the fertilizing by a mixture of compost plus mycorbiza, and vertical position on the stem of petung bamboo (Dendrocalamus asper (Schult. F.) Backer ex Heyne) on its physical and mechanical properties. The properties as observed or responses covered density, moisture content, modulus of elasticity (MOE) and modulus of rupture (MOR).

The fertilizing was conducted in the early cultivation with the compost plus mycorbiza $5 \mathrm{~kg} / \mathrm{hole}$ on the $5 \times 5 \mathrm{~m}^{2}$ of clumps area. The bamboo samples was taken by 20 pieces from 3 clumps for the physical and mechanical examinations. Samples was cut at the third internode (40 50 cm) from bottom as long as more or less $7 \mathrm{~m}$. Every culms is divided by 3 according to vertical position (bottom, middle and top).

Research result revealed that the stem diameter and thickness of petung bamboo that was fertilized were greater than those of bamboo without fertilizer (control). It turned out that the average density and moisture content did not revealed consistency between treatment (fertilizing) and control on particular vertical position in the bamboo stem.

Compared to the overall mean, average MOE of the bottom and middle portions of fertilized bamboo stem decreased by $46 \%$ and $44 \%$, respectively. However, MOE of the top portion increased by $10 \%$. Likewise, average MOR of the bottom portion decreased by $44 \%$, while that of middle and top portions increased by $2 \%$, respectively.
\end{abstract}

Keywoeds: Bamboo, fertilization, physical and mechanicalproperties.

\begin{abstract}
ABSTRAK
Penelitian ini bertujuan menganalisa pengaruh pemberian pupuk kompos plus mikoriza dan posisi vertikal batang terhadap sifat fisik dan mekanik bambu petung (Dendrocalamus asper (Schult. F.) Backer ex Heyne). Respon yang diamati adalah kerapatan, kadar air, modulus elastisitas (MOE) dan modulus patah (MOR).

Pemupukan dilakukan pada awal penanaman dengan pupuk kompos plus mikoriza sebanyak 5 $\mathrm{kg} /$ lubang tanam dengan ukuran setiap rumpun $5 \times 5 \mathrm{~m}^{2}$. Bambu percobaan diambil 20 batang dari 3 rumpun untuk penelitian sifat fisik dan mekanik. Contoh uji diambil pada ruas ke-3 $(40-50 \mathrm{~cm})$ dari
\end{abstract}


bagian pangkal batang sepanjang lebih kurang $7 \mathrm{~m}$. Kemudian dibagi 3 menurut ketinggian batang (pangkal, tengah dan ujung).

Hasil penelitian menunjukkan, diameter dan tebal bambu yang diberi perlakuan jauh lebih besar dibandingkan dengan bambu petung yang tidak diberi perlakuan. Nilai rata-rata kerapatan dan kadar air tidak menunjukkan konsistensi antara perlakuan dengan kontrol pada posisi vertikal batang. Nilai ratarata MOE hasil pemupukan pada bagian pangkal menurun $46 \%$ dan bagian tengah $44 \%$, namun pada bagian ujung meningkat sebesar $10 \%$. Demikian pula MOR, pada bagian pangkal menurun $44 \%$, bagian tengah $44 \%$ dan bagian ujung meningkat sebesar $2 \%$.

Kata kunci : Bambu, pemupukan, sifat fisik, sifat mekanik

\section{PENDAHULUAN}

Bambu adalah tanaman yang tergolong familia Bamboidae, salah satu anggota sub famili rumput. Pertumbuhannya sangat cepat, bahkan pada masa pertumbuhan jenis bambu tertentu dapat tumbuh secara vertikal $5 \mathrm{~cm}$ per jam atau $120 \mathrm{~cm}$ per hari (Siopongco dan Munandar, 1987). Potensi bambu di dunia menurut Sharma (1987) tercatat lebih dari 75 genera dan 1250 species bambu, sedang Uchimura (1980) menyatakan bahwa bambu yang ada di Asia Selatan dan Tenggara kira-kira 80\% dari keseluruhan bambu yang ada di dunia dan di Indonesia ditemukan sekitar 60 jenis tanaman bambu. Pada umumnya bambu ditemukan di tempat terbuka dan bebas dari genangan air mulai dari dataran rendah sampai pegunungan dengan ketinggian sekitar $300 \mathrm{~m}$ dpl. Jenis bambu yang sering digunakan oleh masyarakat di Indonesia adalah bambu tali, bambu petung, bambu andong, bambu legi dan bambu hitam. Bambu dalam bentuk bulat digunakan sebagai bahan konstruksi rumah, gudang, jembatan, pipa saluran air, alat rumah tangga dan barang kerajinan, dalam bentuk belahan dapat dibuat bilik (gedek), reng, pagar dan sebagainya. Bambu dalam bentuk belahan juga dibuat bambu lamina yang digunakan sebagai bahan baku mebel dan farquet flooring (Sulastiningsih et al., 2005).

Hampir seluruh bagian dari tanaman bambu dapat dimanfaatkan antara lain; bagian ujung bambu (daun dan cabang) untuk seni dan kerajinan tangan, obat-obatan, karbondioksida $\left(\mathrm{CO}_{2}\right)$. Bagian tengah (batang bambu) untuk rumah dan perabot rumah tangga. Bagian pangkal bambu untuk bahan bangunan, arang, perabot. Bagian bambu yang masih muda (rebung) untuk makanan, akar bambu berfungsi sebagai penyerap air tanah, pencegah erosi, penyaring bahan berbahaya/racun dalam tanah, arang, obat tradisional (Garland,2003).

Di negara-negara Asia bambu telah digunakan sebagai peralatan rumah tangga seperti keranjang, sumpit, alat tenun, alat pancing, kotak mainan, barang kerajinan, kursi dan lain-lain. Bambu juga telah digunakan secara luas pada bangunan seperti lantai, plafond, dinding, jendela, pintu, pagar, penutup atap, rangka batang, kaso, gording. Selain itu bambu juga digunakan sebagai bahan struktur berat seperti jembatan, fasilitas pengangkutan air dan perancah bangunan tinggi (Latif, 1990).

Dalam menentukan kesesuaian pemanfaatannya, bambu dipengaruhi oleh sifat-sifat anatomi, kimia, fisik dan mekanik. Beberapa hal yang mempengaruhi sifat fisik dan mekanik bambu adalah umur, posisi ketinggian batang, diameter, tebal daging bambu, posisi 
pembebanan (pada buku atau ruas), posisi radial dari luar sampai ke bagian dalam dan kadar air bambu. Hasil penelitian Suranto (1992) dan Morisco (1999) menyatakan bahwa kuat tarik sejajar serat, tekan sejajar serat, MOE dan MOR berpengaruh nyata terhadap posisi ketinggian batang, semakin tinggi posisi ketinggian, semakin besar kekuatan mekanisnya.

Bambu petung (Dendrocalamus asper (Schult. F.) Backer ex Heyne) merupakan salah satu dari beberapa jenis bambu yang banyak dimanfaatkan masyarakat Indonesia. Bambu jenis ini mempunyai rumpun agak rapat, dapat tumbuh di dataran rendah sampai pegunungan dengan ketinggian $2000 \mathrm{~m}$ dpl. Pertumbuhannya cukup baik khususnya untuk daerah yang tidak terlalu kering, warna kulit batang hijau kekuning-kuningan. Batang dapat mencapai panjang 10 - $14 \mathrm{~m}$, panjang ruas berkisar antara $40-60 \mathrm{~cm}$ dengan diameter $6-15 \mathrm{~cm}$ dan tebal dinding $10-15 \mathrm{~mm}$.

Kandungan hara pada berbagai lokasi tempat tumbuh bambu berbeda-beda, oleh karena itu perlu dilakukan pemupukan. Pemupukan memegang peranan penting dalam upaya meningkatkan hasil panen bambu, namun jenis pupuk yang digunakan harus sesuai dengan tujuan pemupukan. Dalam hal pemupukan terhadap tanaman bambu bertujuan memperbanyak dan mempercepat tumbuhnya tunas atau bibit di samping meningkatkan jumlah produksi bambu. Unsur hara yang sangat penting bagi pertumbuhan tanaman adalah $\mathrm{P}, \mathrm{Mg}, \mathrm{Ca}$, dan $\mathrm{K}$. Masing-masing unsur hara memberikan dampak yang berbeda antara lain, unsur hara $\mathrm{P}$ berperan dalam pengendalian proses fisiologi, $\mathrm{K}$ berperan dalam proses fotosintesa dan pernafasan (Sunarlim et al., 1991). Sedangkan Ca memperkuat tangkai tanaman dan perkembangan pucuk (Komarayati, 2002). Kemudian nilai tukar kation (KTK) merupakan sifat yang erat hubungannya dengan kesuburan tanah, pupuk organik dengan KTK tinggi mampu menyerap dan menyediakan unsur hara lebih besar dari pada pupuk organik dengan nilai KTK rendah (Saifudin, 1989).

Bambu petung yang diambil sebagai bahan penelitian ditanam pada lahan bekas tanaman ketela dimana lingkungan tempat tumbuhnya termasuk kategori kurang subur, banyak ditumbuhi ilalang dan semak lainnya. Kandungan hara makro N, P, K rendah sehingga perlu penambahan pupuk kompos ditambah dengan mikoriza.

Tujuan penelitian ini adalah mengetahui pengaruh pemupukan dengan kompos plus mikoriza dan posisi vertikal batang terhadap beberapa sifat fisik dan mekanik bambu betung yaitu kerapatan, kadar air, modulus elastisitas dan modulus patah.

\section{BAHAN DAN METODA}

\section{A. Bahan Penelitian}

Jenis bambu yang digunakan sebagai bahan penelitian adalah bambu petung (Dendrocalamus asper (Schult. F.) Backer ex Heyne) yang diambil dari Desa Sempora Cibinong Kabupaten Bogor. Lokasi tanaman terletak pada ketinggian $230 \mathrm{~m}$ dpl, variasi suhu berkisar $22-36^{\circ} \mathrm{C}$ dengan kelembaban relatif $25-80 \%$.

Bahan dan peralatan yang digunakan dalam penelitian ini adalah pupuk kompos, gergaji tangan, meteran, timbangan, oven, peralatan untuk menganalisa kandungan kimia tanah dan mesin uji universal (UTM) untuk mengamati sifat mekanik bambu. 


\section{B. Metoda}

1. Pemupukan

- Bambu ditanam secara vegetatif dari stek batang yang berasal dari mata tunas pada ruas tumbuh pohon induk berumur 2 tahun. Bibit tersebut berasal dari rumpun koleksi kebun percobaan Puspitek Serpong.

- Pemupukan dilakukan pada awal penanaman dengan pupuk kompos yang diperkaya bakteri pelarut fosfat dan mikoriza sebanyak $5 \mathrm{~kg} /$ lubang tanam dengan ukuran setiap rumpun $5 \times 5 \mathrm{~m}^{2}$.

- Pada tahun kedua dilakukan pemupukan masing-masing sebanyak $1 \mathrm{~kg} / \mathrm{rumpun}$.

- Selain perawatan rutin, dilakukan penambahan pupuk $2 \mathrm{~kg}$ per rumpun pada tahun ke3 setelah panen perdana, bersamaan dengan penggemburan dan perluasan rumpun bambu. Penggunaan pestisida tidak dilakukan, tetapi hanya sanitasi lingkungan untuk pencegahan hama dan penyakit.

\section{Pengambilan sampel}

- Bahan untuk penelitian diambil setelah bambu berumur 4 tahun 9 bulan pada akhir musim kemarau (pertengahan Oktober 2008).

- Bambu percobaan diambil 20 batang dari 3 rumpun pada petak perlakuan, sebagian besar digunakan untuk penelitian lain dan sisanya untuk penelitian sifat fisik dan mekanik. Bambu kontrol adalah petak yang tidak dipupuk terpisah dari petak perlakuan., masing-masing contoh dipotong pada ruas ke-3 (40-50 cm dari bagian pangkal batang sepanjang lebih kurang $7 \mathrm{~m}$. Kemudian dibagi 3 menurut ketinggian batang (pangkal, tengah dan ujung) seperti Gambar1a. 

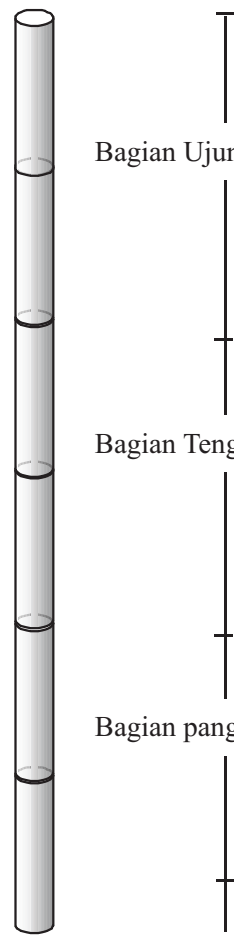

Bagian Ujung (Top), $2 \mathrm{~m}$

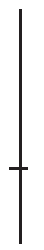

Bagian Tengah (Middle), $2 \mathrm{~m}$

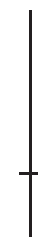

Bagian pangkal (Bottom), $2 \mathrm{~m}$

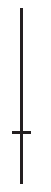

a. Pembagian posisi vertikal

(Distribution of vertical position)

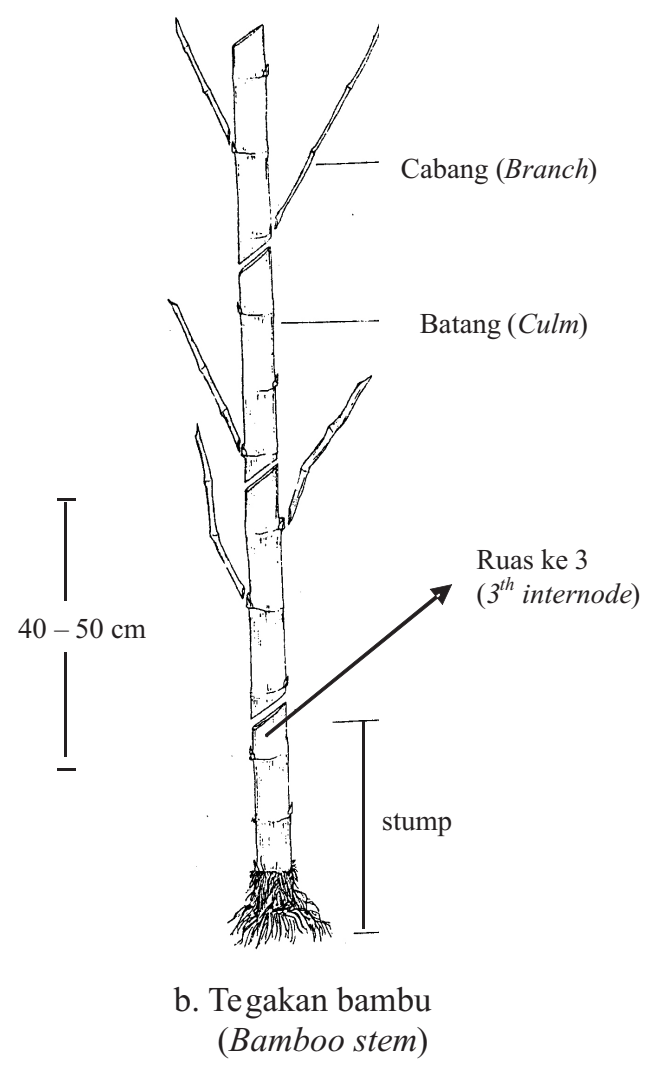

\section{Gambar1. Cara pengambilan contoh uji sifat fisik dan mekanik bambu} Figure 1. Method of sampling for physical and mechanical properties of bamboo

3. Pengujian

a. Pengujian lentur statik:

Sistem pembebanan tidak dibedakan antara beban pada buku atau pada ruas seperti pada Gambar 2. 


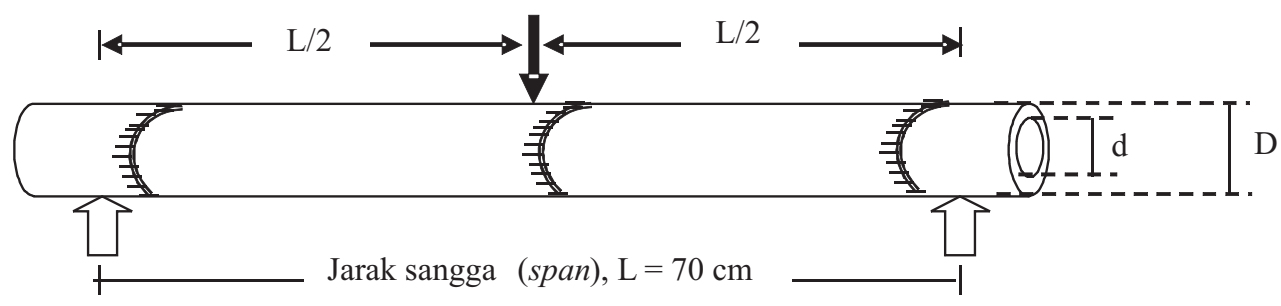

Keterangan (Remarks) : $\mathrm{D}=$ diameter total (total diameter), $\mathrm{d}=$ diameter dalam (inner diameter)

Gambar 2. Tata cara pengujian keteguhan lentur statik bambu.

Figure 2. Metbods of static bending test of bamboo.

Pengujian menggunakan mesin UTM berkapasitas 20 ton gaya dengan kecepatan beban statis $50 \mathrm{~kg} /$ menit.

b. Kerapatan dan kadar air

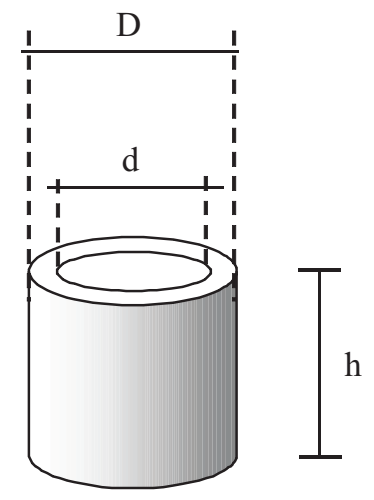

Keterangan (remarks) :

$\mathrm{D}=$ Diameter total (total diameter)

$\mathrm{d}=$ diameter dalam (inner diameter)

$\mathrm{h}=$ tinggi contoh uji (beight)

Gambar 3. Contoh uji kerapatan dan kadar air bambu

Figure 3. The specimens of density and moisture content of bamboo

4. Pengolahan data

Data hasil penelitian ditabulasi dan dihitung nilai rata-ratanya, kemudian untuk mengetahui faktor-faktor pengaruh dalam percobaan dilakukan analisa keragaman menggunakan rancangan acak lengkap faktorial A x B di mana A adalah perlakuan terdiri dari 2 tingkat faktor yaitu $\mathrm{a}_{1}=$ kontrol dan $\mathrm{a}_{2}=$ pemupukan. $\mathrm{B}$ adalah posisi ketinggian batang terdiri dari 3 tingkat faktor yaitu $b_{1}=$ pangkal, $b_{2}=$ tengah dan $b_{3}=$ ujung. Sifat-sifat yang dianalisa adalah $\mathrm{Y}_{1}=$ kerapatan, $\mathrm{Y}_{2}=$ kadar air, $\mathrm{Y}_{3}=$ MOE dan $\mathrm{Y}_{4}=\mathrm{MOR}$, setiap perlakuan diulang tiga kali. 


\section{HASIL DAN PEMBAHASAN}

\section{A. Kandungan Kimia Tanah}

Kandungan kimia tanah sebagai penghara sebelum pemupukan tercantum dalam Tabel 1.

Tabel1. Hasil analisis tanah tempat tumbuh bambu percobaan Table 1. Result of soil analysis on site growing of bamboo treatments

\begin{tabular}{|l|c|c|}
\hline \multicolumn{1}{|c|}{$\begin{array}{c}\text { Kandungan kimia tanah } \\
\text { (Content of soil chemistr) }\end{array}$} & $\begin{array}{c}\text { Jumlah } \\
(\text { Total) }\end{array}$ & $\begin{array}{c}\text { Satuan } \\
(\text { Unit })\end{array}$ \\
\hline $\begin{array}{l}\text { 1. Bahan organik (Organic matters) : } \\
\text { a. C }\end{array}$ & 1,72 & $\%$ \\
b. $\mathrm{N}$ & 0,11 & $\%$ \\
c. $\mathrm{P}_{2} \mathrm{O} 5$ & 13 & $\mathrm{mg} / 100 \mathrm{~g}$ \\
d. $\mathrm{K}_{2} \mathrm{O}$ & 18 & $\mathrm{mg} / 100 \mathrm{~g}$ \\
\hline A. Nilai tukar kation (Cation exchange value) & & \\
a. Ca & 11,41 & $\mathrm{me} / 100 \mathrm{~g}$ \\
b. Mg & 3,07 & $\mathrm{me} / 100 \mathrm{~g}$ \\
c. K & 3,57 & $\mathrm{me} / 100 \mathrm{~g}$ \\
d. Na & 0,30 & $\mathrm{me} / 100 \mathrm{~g}$ \\
\hline Kation bebas (Free cation) : & 68 & $\%$ \\
$\quad$ Tekstur tanah (Soil texture) : & & $\%$ \\
a. Pasir (sand) & 19 & $\%$ \\
b. Debu (ash) & 49 & $\%$ \\
c. Tanah liat (clay) & 32 & \\
\hline
\end{tabular}

Pada Tabel 1 tampak bahwa unsur C organik 1,72\%, N total 0,11\%, nisbah C/N 15,64, $\mathrm{P}_{2} \mathrm{O}_{5}$ 0,13\% dan $\mathrm{K}_{2} \mathrm{O}$ total $0,18 \%$. Kandungan kimia tanah tersebut tergolong sangat rendah (Komarayati, 2008), sehingga perlu penambahan pupuk organik untuk meningkatkan kandungan hara tanah pada pertumbuhan bambu percobaan.

\section{B. Perbedaan Pertumbuhan Setelah Pemupukan}

Hasil pemupukan bambu petung dapat meningkatkan pertumbuhan primer maupun sekunder (diameter dan tebal daging bambu) seperti ditampilkan pada Tabel 2. 
Tabel 2. Diameter dan ketebalan buluh bambu percobaan. Table 2. Diameter and thickness of the bamboo treatments.

\begin{tabular}{|l|l|l|l|l|l|l|}
\hline \multirow{2}{*}{$\begin{array}{c}\text { Perlakuan } \\
\text { (Treatment) }\end{array}$} & \multicolumn{3}{|c|}{$\begin{array}{c}\text { Diameter batang } \\
\text { Culm diameter })\end{array}$} & \multicolumn{3}{c|}{$\begin{array}{c}\text { Tebal buluh bambu } \\
\text { (Wall thickness) }\end{array}$} \\
\cline { 2 - 7 } & $\begin{array}{c}\text { Pangkal } \\
(\text { bottom })\end{array}$ & $\begin{array}{c}\text { Tengah } \\
(\text { medium })\end{array}$ & $\begin{array}{c}\text { Ujung } \\
(\text { top })\end{array}$ & $\begin{array}{c}\text { Pangkal } \\
(\text { bottom })\end{array}$ & $\begin{array}{c}\text { Tengah } \\
(\text { medium })\end{array}$ & $\begin{array}{c}\text { Ujung } \\
(\text { top })\end{array}$ \\
\hline Kontrol (control) & 8,68 & 8,43 & 6,96 & 1,34 & 1,10 & 0,79 \\
\hline $\begin{array}{l}\text { Pemupukan } \\
\text { (fertilization) }\end{array}$ & 12,65 & 11,32 & 8,56 & 2,14 & 1,48 & 0,99 \\
\hline $\begin{array}{l}\text { Peningkatan } \\
\text { (improvement) }(\%)\end{array}$ & 45,74 & 34,28 & 22,99 & 59,70 & 34,55 & 25,32 \\
\hline
\end{tabular}

Pada Tabel 2 tampak perbedaan ukuran diameter dan tebal buluh yang cukup signifikan, hal ini disebabkan oleh penambahan kandungan unsur hara yang terkandung dalam pupuk kompos plus mikoriza. Unsur hara yang sangat penting bagi pertumbuhan tanaman adalah $\mathrm{P}$, $\mathrm{Mg}$, Ca, dan K. Masing-masing unsur hara memberikan dampak yang berbeda antara lain, unsur hara $\mathrm{P}$ berperan dalam pengendalian proses fisiologi, $\mathrm{K}$ berperan dalam proses fotosintesa dan pernafasan (Sunarlim et al., 1991). Menurut Gardner et al. (1991), parameter yang menunjukkan potensi tanaman melakukan fotosintesis dan potensi produktif tanaman adalah Indeks Luas Daun (ILD) karena permukaan daun merupakan organ utama tumbuhan untuk melakukan fotosintesis. Perkembangan ILD dipengaruhi oleh jumlah dosis pupuk yang diberikan, meningkatnya dosis pupuk dapat meningkatkan konsentrasi hara dalam tanah, terutama N, P dan K serta unsur lainnya. Pada tanaman bambu, bentuk dan susunan daun yang tidak menutup satu sama lain menyebabkan proses fotonsintesis, transportasi makanan dan pernapasan berlangsung dengan cepat. Dengan demikian penambahan unsur hara yang terkadung dalam pupuk kompos plus mikoriza dapat meningkatkan pertumbuhan diameter dan tinggi batang bambu.

\section{Sifat Fisik dan Mekanik Bambu}

Sifat fisik dan mekanik bambu merupakan sifat dasar yang perlu diketahui sebelum digunakan, baik sebagai komponen struktur maupun non struktur. Hasil penelitian sifat fisik dan mekanik bambu percobaan yang meliputi kerapatan, kadar air, MOE dan MOR berdasarkan posisi vertikal batang ditampilkan pada Tabel3. 
Tabel 3. Rata-rata sifat fisik dan mekanik bambu petung berdasarkan posisi vertikal Table 3. Average of physical and mechanical properties of petung bamboo tested based on vertical position

\begin{tabular}{|c|c|c|c|c|c|}
\hline \multirow{2}{*}{$\begin{array}{l}\text { Perlakuan } \\
\text { (Treatment) }\end{array}$} & \multirow{2}{*}{$\begin{array}{l}\text { Posisi vertikal } \\
\text { (Vertical position) }\end{array}$} & \multirow{2}{*}{$\begin{array}{c}\text { Kerapatan } \\
(\text { Density) } \\
\left(\mathrm{g} / \mathrm{cm}^{3}\right)\end{array}$} & \multirow{2}{*}{$\begin{array}{c}\text { Kadar air } \\
\text { (Moisture Content) } \\
(\%)\end{array}$} & (MOE) & (MOR) \\
\hline & & & & \multicolumn{2}{|c|}{$\left(\mathrm{kg} / \mathrm{cm}^{2}\right)$} \\
\hline \multirow{3}{*}{$\begin{array}{l}\text { Kontrol } \\
\text { (Control) }\end{array}$} & Pangkal (bottom) & 0,822 & 15,37 & 13.234 & 439 \\
\hline & Tengah (middle) & 0,763 & 15,20 & 18.091 & 552 \\
\hline & Ujung (top) & 0,804 & 14,80 & 29.428 & 610 \\
\hline \multirow{3}{*}{$\begin{array}{l}\text { Pemupukan } \\
\text { (Fertilization) }\end{array}$} & Pangkal (bottom) & 0,795 & 15,77 & 7.121 & 245 \\
\hline & Tengah (middle) & 0,850 & 16,73 & 10.110 & 307 \\
\hline & Ujung (top) & 0,894 & 14,63 & 32368 & 623 \\
\hline
\end{tabular}

Catatan. (Notes) : Setiap pengukuran diulang 3 kali (The number of replication is 3)

Pada Tabel 3 dapat diamati bahwa sifat fisik (kerapatan dan kadar air) tidak menunjukkan konsistensi bahkan hampir sama antara perlakuan dengan kontrol pada posisi vertikal batang. Fakta ini menunjukkan bahwa pada kondisi kadar air yang sama, kerapatan bambu ini cenderung tidak berbeda. Karena kerapatan bambu salah satunya dipengaruhi oleh kandungan air yang terdapat di dalam sel-sel parenkim dan gugus vaskuler. Pengukuran kerapatan, MOE dan MOR dilakukan pada kadar kering udara (12-20\%).

Nilai rata-rata MOE hasil pemupukan pada bagian pangkal, tengah dan ujung masingmasing $7.121,30 \mathrm{~kg} / \mathrm{cm}^{2}, 10.109,5 \mathrm{~kg} / \mathrm{cm}^{2}$ dan $32.367,64 \mathrm{~kg} / \mathrm{cm}^{2}$. MOR rata-rata hasil pemupukan masing-masing 245,28 kg/ $\mathrm{cm}^{2}$ (pangkal), $306.63 \mathrm{~kg} / \mathrm{cm}^{2}$ (tengah) dan 622.99 $\mathrm{kg} / \mathrm{cm}^{2}$ (ujung). Dibandingkan dengan bambu petung tanpa pemupukan, MOE pada bagian pangkal menurun 46\% dan bagian tengah 44\%, namun pada bagian ujung meningkat sebesar 10\%. Demikian pula MOR, pada bagian pangkal menurun 44\%, bagian tengah 44\% dan bagian ujung meningkat sebesar 2\% seperti ditunjukkan pada Gambar 6. Berdasarkan data di atas dapat dikemukakan bahwa pemupukan dengan kompos plus mikoriza dapat meningkatkan ukuran dan memperbanyak tunas bambu petung tetapi menurunkan sifak mekaniknya. Hal ini bisa dijelaskan bahwa pemupukan dapat mempercepat proses pertumbuhan yang dirangsang oleh unsur hara yang terkandung di dalam pupuk. Sifat kimia yang erat hubungannya dengan kesuburan adalah kapasitas tukar kation (KTK), karena KTK berfungsi menyerap dan menyediakan unsur hara bagi pertumbuhan tanaman (Saifudin, 1989). Sedangkan sifat mekanik bambu ditentukan oleh porsi ketebalan kulit, karena bagian terkuat pada bambu adalah bagian kulit dibandingkan dengan kekuatan bambu bagian dalam (Morisco, 1999). 


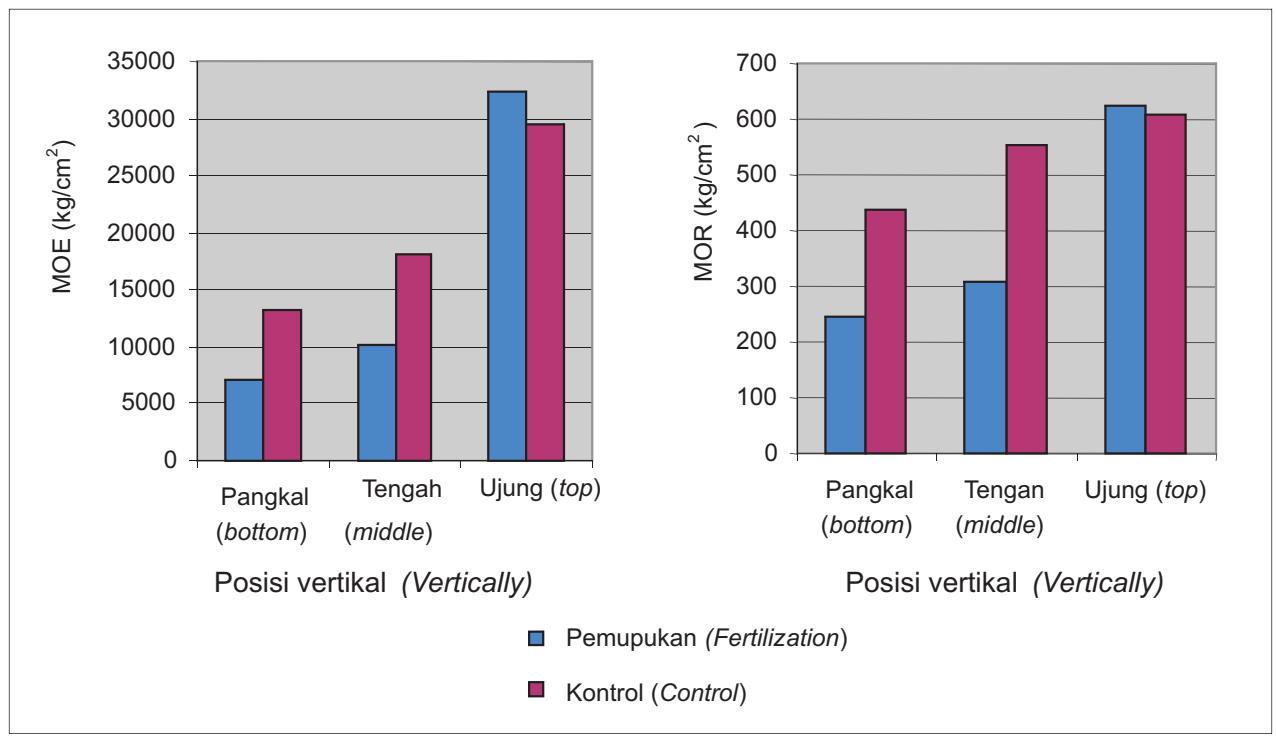

\section{Gambar 6. Pengaruh pemupukan terhadap MOE dan MOR Figure 6. The effect of fertilizing to $M O E$ and $M O R$}

Pada Tabel 3 dapat dilihat pula bahwa semakin tinggi posisi vertikal batang semakin besar pula nilai sifat mekaniknya (MOE dan MOR). Hal ini dapat dikatakan bahwa kekuatan bambu tidak ditentukan oleh ketebalan buluh melainkan oleh ketebalan kulit luar. Selain itu sifat-sifat batang bambu ditentukan oleh sifat anatominya seperti sel paremkim, gugus vaskuler yang mengandung pembuluh, serabut berdinding tebal dan pembuluh tapis (Liese, 1985). Kemudian dikemukakan oleh Nuryatin (2004), ikatan vaskuler yang menyusun batang bambu petung secara alami pada bagian pangkal, tengah dan ujung serta bagian luar, tengah dan dalam pada posisi melintang adalah tipe IV dengan jumlah ikatan vaskular berkisar 27 93 buah per $\mathrm{cm}^{2}$. Sehingga antara bagian pangkal hingga ujung batang terdapat peningkatan jumlah ikatan vaskular dan berkontribusi untuk meningkatkan kerapatan dan sifat mekanik. Namun pada bambu percobaan yang diberi pupuk kompos plus mikoriza berbeda dengan bambu yang tumbuh alami, karena bambu yang diberi pupuk pada umur panen yang sama pertumbuhan diameter dan ketebalannya meningkat. Berdasarkan posisi ketinggian, ketebalan kulit relatif seragam pada sepanjang batang, sedangkan tebal bambu sangat bervarisai dari pangkal sampai ujung. Oleh karena itu bambu tipis akan mempunyai porsi kulit lebih besar dari bambu tebal, sehingga kekuatan rata-ratanya menjadi tinggi.

Hasil analisa sidik ragam sifat fisik dan mekanik bambu hasil percobaan disajikan pada Tabel 4. 
Tabel4. Sidik ragam pengaruh perlakuan pupuk dan posisi vertikal batang terhadap sifat fisik dan mekanik bambu petung

Table 4. Analysis of variance for the effect of fertilizing and vertical position on physical and mechanical properties of petung bamboo

\begin{tabular}{|l|c|c|c|c|c|}
\hline \multirow{2}{*}{$\begin{array}{c}\text { Sumber } \\
\text { (Sources) }\end{array}$} & \multirow{2}{*}{$\begin{array}{c}\mathrm{db} \\
(d f)\end{array}$} & \multicolumn{4}{|c|}{ Nilai $\mathrm{F}_{\text {hitung }}\left(\mathrm{F}_{\text {calculated }}\right)$} \\
\cline { 5 - 7 } & $\mathrm{Y}_{1}$ & $\mathrm{Y}_{2}$ & $\mathrm{Y}_{3}$ & $\mathrm{Y}_{4}$ \\
\hline - Perlakuan (Treatment) (A) & 1 & $10,96^{*}$ & $2,03^{\text {tn }}$ & $24,21^{*}$ & $9,15^{\text {tn }}$ \\
\hline - Posisi vertikal (Vertical position) (B) & 2 & $2,91^{\text {tn }}$ & $5,74^{* *}$ & $5,42^{\text {tn }}$ & $13,63^{* *}$ \\
\hline - Interaksi (Interaction) (A $\times \mathrm{B})$ & 2 & $5,74^{* *}$ & $2,64^{\text {tn }}$ & $2,45^{\text {tn }}$ & $3,02^{\text {tn }}$ \\
\hline
\end{tabular}

Keterangan (Remarks) : * berbeda nyata (significant different); ** sangat berbeda nyata (very significant different); th tidak berbeda nyata (non significant different); $\mathrm{Y}_{1}=$ kerapatan (density); $\mathrm{Y}_{2}=$ kadar air (moisture content); $\mathrm{Y}_{3}=\mathrm{MOE}$ dan $\mathrm{Y}_{4}=\mathrm{MOR}$

Pada Tabel 4 dapat dilihat bahwa pemupukan berpengaruh nyata terhadap kerapatan dan MOE, sedangkan terhadap kadar air dan MOR tidak menunjukkan perbedaan yang nyata. Hal ini disebabkan oleh kandungan alpha selulosa, holoselulosa dan lignin yang terdapat di dalam dinding sel. Kandungan holoselulosa dan lignin bambu petung menurut Manuhuwa (2007) masing $73.63 \%$ dan $27.37 \%$ dengan tebal dinding sel serat 0.77 mikron. Pada bambu percobaan yang diberi pupuk nilai-nilai tersbut belum tercapai. Tetapi pada bagian tengah dan ujung nilai kerapatannya lebih tinggi karena ketebalannya lebih kecil dan porsi kulitnya lebih besar dibandingkan dengan bambu yang tidak dipupuk. Pemberian pupuk kompos plus mikoriza ini tidak mempengaruhi perubahan kadar air dan kekuatan lentur bambu. Berdasarkan analisa statistik dapat dinyatakan bahwa pemberian pupuk kompos plus mikoriza justru menurunkan kekuatan lentur.

Posisi vertikal batang berpengaruh sangat nyata terhadap kadar air dan kekuatan lentur bambu (MOR) dan interaksi antara pemupukan dengan posisi vertikal batang hanya berpengaruh sangat nyata terhadap kerapatan bambu. Hal ini hampir sama dengan hasil penelitian Suranto (1992) bahwa posisi vertikal batang bambu apus (Gigantochloa apus Kurz.) berpengaruh secara nyata terhadap MOE dan MOR namun tidak memperlihatkan pola keteraturan dalam arah vertikal batang. Dapat ditambahkan bahwa hal ini memberikan informasi untuk menentukan kesesuaian penggunaan bambu pada tiap posisi vertikal batang bambu.

\section{KESIMPULAN}

Dari hasil penelitian dapat disimpulkan :

1. Diameter batang dan ketebalan buluh bambu hasil pemupukan meningkat pada bagian pangkal, tengah maupun ujung batang.

2. MOE dan MOR bambu setelah pemupukan dengan pupuk kompos plus mikoriza menurun pada bagian pangkal dan tengah dan meningkat pada bagian ujung batang. 
3. Berdasarkan analisis keragaman dapat dinyatakan bahwa pemberian pupuk kompos plus mikoriza berpengaruh secara nyata pada taraf 5\% terhadap kerapatan dan MOE. Sedangkan posisi vertikal batang bambu berpengaruh sangat nyata terhadap kadar air dan MOR.

\section{DAFTAR PUSTAKA}

Garland L., 2003. Cara Mengawetkan Bambu dengan Vertical Soak Diffusion (VSD), Environmental Bamboo Foundation, Bali. Indonesia.

Komarayati, S., 2005. Karakteristik Pupuk Organik Limbah Padat Industri Pulp Plus Arang Serbuk Gergaji. Jurnal Penelitian Hasil Hutan. Vol. 26(4):313-322. Pusat Litbang Hasil Hutan. Bogor.

Latif A., M., W.A.W. Tarmeze and A. Fauzidah. 1990. Anatomical features and mechanical properties of three Malaysian bamboos. Journal Tropical Sciense. 2(3):227-234. Kuala Lumpur.

Liese W. 1985. Anatomy and properties of bamboo. Proceeding of the International Bamboo Workshop. Oct. 6 14, 1985. Hangzhou, People's Republic of Chine. Pp. 196-208.

Manuhuwa E., dan M. Loiwatu. 2007. Komponen Kimia dan Anatomi Tiga Jenis Bambu. Jurnal Ilmiah. Jurusan Kehutanan No. 11. Fakultas Pertanian Universitas Patimura. Ambon.

Morisco, 1999. Rekayasa Bambu. Nafiri Offset. Yogjakarta

Nuryatin N., 2004. Studi Sifat Anatomi pada Lima Jenis Bambu. Jurnal Penelitian UNIB Vol. $\mathrm{X}(1)$ : 11-19. UNIB.

Saifudin, S. 1989. Fisika Kimia Tanah. Pustaka Buana. Jakarta.

Sharma, Y.M.L., 1987. Inventory and resources of bamboo: 4 17, In Rao, A.N.,: Dhanarajan, G. \& Shastry, C.B., Recent Research on Bamboo, C.A.F., China and IDRC. Canada.

Sioponco, J.O., and Munandar, M., 1987. Technology Manual on Bamboo as Building Material. RENAS-BMTCS. Philippines.

Sulastiningsih, I.M., Nurwati H dan Karnita Y. 2005. Prosiding Seminar Hasil Litbang Hasil Hutan. Pusat Penelitian dan Pengembangan Hasil Hutan. Bogor.

Suranto Y. (1992). Pengaruh Umur dan Posisi Vertikal Batang Terhadap Beberapa Sifat Mekanik Bambu Apus (Gigantochloa apus Kurz.). Buletin No. 22 Fahutan UGM Yogjakarta.

Uchimura, E., 1980. Bamboo Cultivation; 151-160. In Lessard, G. \& Chouinard, A., Bamboo Research in Asia, IDRC. Canada. 
Lampiran 1. Hasil analisis keragaman pengaruh pemupukan dan posisi vertikal batang terhadap sifat fisik dan mekanik bambu.

Appendix 1. The result of analysis of variance for the effect of fertilizing and vertical position to bamboo physical and mechanical properties.

Tabel 1. Anova untuk kerapatan (Y1)

Table 1. Analysis of variances for density (Y1)

\begin{tabular}{|c|c|c|c|c|c|}
\hline Sumber (Sources) & $\begin{array}{l}\mathrm{db} \\
(d f)\end{array}$ & $\mathrm{JK}(S S)$ & KT (MS) & $\begin{array}{c}\text { F-hitung } \\
(\text { F-calc. })\end{array}$ & $\operatorname{Pr}>F$ \\
\hline $\begin{array}{l}\text { Petak utama (Primary block) } \\
\text { - Perlakuan (Treatment) (A) } \\
\text { - Acak petak utama } \\
\text { (Randomize of primary } \\
\text { block) }\left(\mathrm{e}_{1}\right)\end{array}$ & $\begin{array}{l}1 \\
4\end{array}$ & $\begin{array}{l}0.002260011 \\
0.02676356\end{array}$ & $\begin{array}{l}0.02260011 \\
0.00206178\end{array}$ & $10.96^{*}$ & 0.0296 \\
\hline $\begin{array}{l}\text { Petak sekunder } \\
\text { (Secondary block) } \\
\text { - Posisi vertikal (Vertical } \\
\text { position) (B) } \\
\text { - Interaksi (Interaction) (A x } \\
\text { B) } \\
\text { - Acak petak sekunder } \\
\text { (Randomize of secondary } \\
\text { block) }\end{array}$ & $\begin{array}{l}2 \\
2 \\
26\end{array}$ & $\begin{array}{l}0.01359022 \\
0.02676356 \\
0.06064351\end{array}$ & $\begin{array}{l}0.00679 \\
0.013381 \\
0.002062\end{array}$ & $\begin{array}{l}2.91^{\text {th }} \\
5.74^{* *}\end{array}$ & $\begin{array}{l}0.0722 \\
0.0086\end{array}$ \\
\hline $\begin{array}{l}\text { Total terkoreksi (Corrected } \\
\text { total) }\end{array}$ & 35 & 0.13184456 & & & \\
\hline
\end{tabular}

Tabel 2. Anova untuk kadar air (Y2)

Table 2. Analysis of variances for moisture contents (Y2)

\begin{tabular}{|l|c|l|l|l|l|}
\hline \multicolumn{1}{|c|}{ Sumber } & $\mathrm{db}$ & $\mathrm{JK}$ & $\mathrm{KT}$ & F-hitung & Pr $>$ F \\
\hline $\begin{array}{l}\text { Petak utama } \\
\text { - Perlakuan (A) }\end{array}$ & 1 & 3.12111111 & 3.12111111 & $2.03^{\text {tn }}$ & 0.2271 \\
$\begin{array}{l}\text { - Acak petak utama } \\
\left(\mathrm{e}_{1}\right)\end{array}$ & 4 & & & & \\
\hline Petak sekunder & & & & & \\
- Posisi vertikal (B) & 2 & 9.78000000 & 4.89000000 & $5.74^{* *}$ & 0.0086 \\
- Interaksi (A x B) & 2 & 4.49555556 & 2.24777778 & $2.64^{\text {tn }}$ & 0.0905 \\
- Acak petak & 26 & 22.15111111 & 0.85196581 & & \\
$\quad$ sekunder & & & & & \\
\hline Total terkoreksi & 35 & 45.69000000 & & & \\
\hline
\end{tabular}


Tabel 3 Anova untuk MOE (Y3)

Table 3. Analysis of variances for MOE (Y3)

\begin{tabular}{|l|c|c|c|c|c|}
\hline \multicolumn{1}{|c|}{ Sumber } & $\mathrm{db}$ & $\mathrm{JK}$ & $\mathrm{KT}$ & F-hitung & Pr $>$ F \\
\hline $\begin{array}{l}\text { Petak utama } \\
\text { - Perlakuan (A) } \\
\text { - Acak petak utama } \\
\left(\mathrm{e}_{1}\right)\end{array}$ & 1 & 7886898755.458884000 & 7886898755.458884000 & $24.21^{*}$ & 0.0079 \\
\hline $\begin{array}{l}\text { Petak sekunder } \\
\text { - Posisi vertikal (B) }\end{array}$ & 2 & 1393401938.53928000 & 696700969.26864300 & $5.42^{\text {tn }}$ & 0.0108 \\
- Interaksi (A x B) & 2 & 1093474734.67555000 & 546737367.33777800 & $4.25^{\text {tn }}$ & 0.0253 \\
- Acak petak & 26 & 3344528422.71729000 & & & \\
\hline sekunder & & & & & \\
\hline Total terkoreksi & 35 & 15021475582.90180000 & & & \\
\hline
\end{tabular}

Tabel 4. Anova untuk MOR (Y4)

Table 4. Analysis of variances for MOR (Y4)

\begin{tabular}{|l|c|c|c|c|c|}
\hline \multicolumn{1}{|c|}{ Sumber } & $\mathrm{db}$ & JK & KT & F-hitung & $\operatorname{Pr}>$ F \\
\hline $\begin{array}{l}\text { Petak Utama } \\
\text { - Perlakuan (A) }\end{array}$ & 1 & 32918.05444444 & 32918.05444444 & $9.15^{\text {tn }}$ & 0.0390 \\
- Acak petak utama & 4 & & & & \\
$\quad\left(\mathrm{e}_{1}\right)$ & & & & & \\
\hline Petak Sekunder & & & & & \\
- Posisi vertikal (B) & 2 & 86920.53860000 & 43460.26930000 & $13.63^{* *}$ & 0.0001 \\
- Interaksi (A x B) & 2 & 19238.90335556 & 9619.45167778 & $3.02^{\text {tn }}$ & 0.0663 \\
- Acak petak & 26 & 82901.34657778 & 3188.51332991 & & \\
sekunder & & & & & \\
\hline Total terkoreksi & 35 & 236369.27400000 & & & \\
\hline
\end{tabular}

